\title{
THE DENTAL CHANGES ASSOCIATED WITH KERNIKTERUS
}

\author{
BY \\ R. M. FORRESTER and JOHN MILLER \\ From the Department of Child Health and the Turner Dental School, University of Manchester
}

(RECEIVED FOR PUBLICATION DECEMBER 15, 1954)

It is widely recognized that children who have recovered from haemolytic disease may show green pigmentation of the deciduous teeth. Marsland and Gerrard (1953) have described the condition fully, and the pigment has been identified as biliverdin by Bevis (1954).

The dental changes which are associated with kernikterus have received less attention. Only two references to this subject have been discovered. Koupernik and Buhot (1952), without describing a specific case, mentioned the occurrence of a crescentshaped erosion of the teeth in kernikterus. Kölbl and Rosenkranz (1952) described two cases showing green pigmentation and enamel hypoplasia. All these authors referred to kernikterus following haemolytic disease.

It is the aim of this paper to describe these dental changes in more detail and to draw attention to their significance.

\section{History and Scope of the Investigation}

During a recent review of children who had recovered from haemolytic disease of the newborn several with the typical green teeth were examined. (One of these has been reported previously by Miller in 1951.) It was noted that in no case was there any clinical evidence of kernikterus.

As both green teeth and kernikterus appear, in general, to be manifest in the more severely jaundiced cases of haemolytic disease this finding seemed curious.

Further evidence of the dissociation between green teeth and kernikterus was sought in the literature on dental pigmentation. In the cases recorded by Thursfield (1912), Losch, Brown and Boyle (1940), Boyle and Dinnerman (1941), Parsons (1947), Pickles (1949), Stones (1951) and Tank (1951), there was no mention of the physical or mental state of their patients; Craig (1925), Ellis (1938), Nickerson and Moulton (1943), Potter (1947) and Farquhar (1951), however, recorded their patients as normal, apart from the dental pigmentation. MacRae (1952) described his one patient as normal apart from nerve deafness, but in the light of subsequent knowledge this symptom may well have been an isolated manifestation of kernikterus. Marsland and Gerrard (1953) made no reference in their paper to the general state of their patients, but Gerrard (1954) has stated that three of their 17 cases (Nos. 1, 4 and 6) showed evidence of kernikterus.

In view of these conflicting reports it was decided to review all available cases of kernikterus. Thirteen children were examined: no dental pigmentation was found, but enamel hypoplasia was present in the deciduous teeth of every one. These cases, where kernikterus followed haemolytic disease, will be described as Group I.

While this review was in progress one of us was following up all the known cases of retrolental fibroplasia from two premature nurseries in Manchester (Forrester, Jefferson and Naunton, 1954). Similar dental lesions were discovered in several children who had both retrolental fibroplasia and cerebral palsy. These cases, together with certain others in premature infants, are described separately (Group II).

\section{Note on Enamel Hypoplasia}

Enamel hypoplasia is generally regarded as originating in metabolic disturbances which interfere with the activity of the enamel organ. Minor hypoplastic lesions, such as localized opaque areas in the tooth substance, have been described by many writers; in more severe cases the enamel becomes 'pitted'. In teeth seriously or extensively hypoplastic there is either marked thinning or apparent absence of the enamel in the affected area.

For the purpose of this paper the minor forms of enamel hypoplasia have been disregarded, and the following descriptions apply to the condition reported:

'Mild' denotes discrete pitting of the enamel of the crown of the tooth, 'severe' the coalescence of 
pits to form lines or rings, areas of tooth crown sometimes apparently devoid of enamel.

The site of the hypoplastic area on the crown of a tooth is related to the age at which metabolism was disturbed. Each tooth begins to form at the cusp and grows to form first the crown and later the root. The approximate state of development of the teeth in relation to age is shown in Fig. 1. It will be seen that the incisors are the first teeth to begin to form and are followed by the canines and molars. Thus, a metabolic disturbance at a date corresponding to the seventh month of intrauterine life would be expected to affect the incisor teeth half-way through their development, but would only touch the tips of the canines and molars. A disturbance at or about full-term would be likely to affect the teeth at a later stage of their development and the enamel lesions would appear nearer the gum margin.

\section{Group I : Kernikterus Following Haemolytic Disease}

In this group 13 children with known kernikterus were examined; all showed enamel hypoplasia. There was slight variation in site and considerable variation in severity between children, and in many cases the original lesion appeared to have been modified by attrition or caries. Despite these modifying factors the lesions were easily recognized on the canine teeth as a 'notch' where the layer of enamel suddenly became thinner (Fig. 2). In some cases this notch was detectable only on the buccal surface of the tooth, but often it appeared as a complete 'ring' around the crown. Both the 'notch' and the 'ring' lesions were readily palpable. These 13 cases were so similar medically and dentally that it is not proposed to describe each in detail. In 12 there was a clear history of haemolytic disease due to $\mathrm{Rh}$ incompatibility. In the thirteenth there was haemolytic disease due to ABO incompatibility. This last case and several others showed special features which do, however, merit detailed description.

Case 1 (P.H.). This child, a boy, was one of monovular twins. The mother was $R h$ negative with strong antibodies. She had had four previous pregnancies: the first three children had been normal but the fourth had died of haemolytic disease on the third day of life. Delivery took place one week before the estimated date. The twin (P.H.) who is the subject of this report had a birth weight of $6 \mathrm{lb} .8 \mathrm{oz}$. The Coombs test was positive. The haemoglobin of the peripheral blood shortly after birth was $92 \%$; jaundice was apparent within the first 12 hours of life. He was thought to be mildly affected and no exchange transfusion was done. He rapidly became deeply jaundiced, feverish and drowsy and developed neck stiffness. The jaundice took many weeks to subside, but there was never any serious degree of anaemia and no transfusions were needed. By the

\section{UPPER}

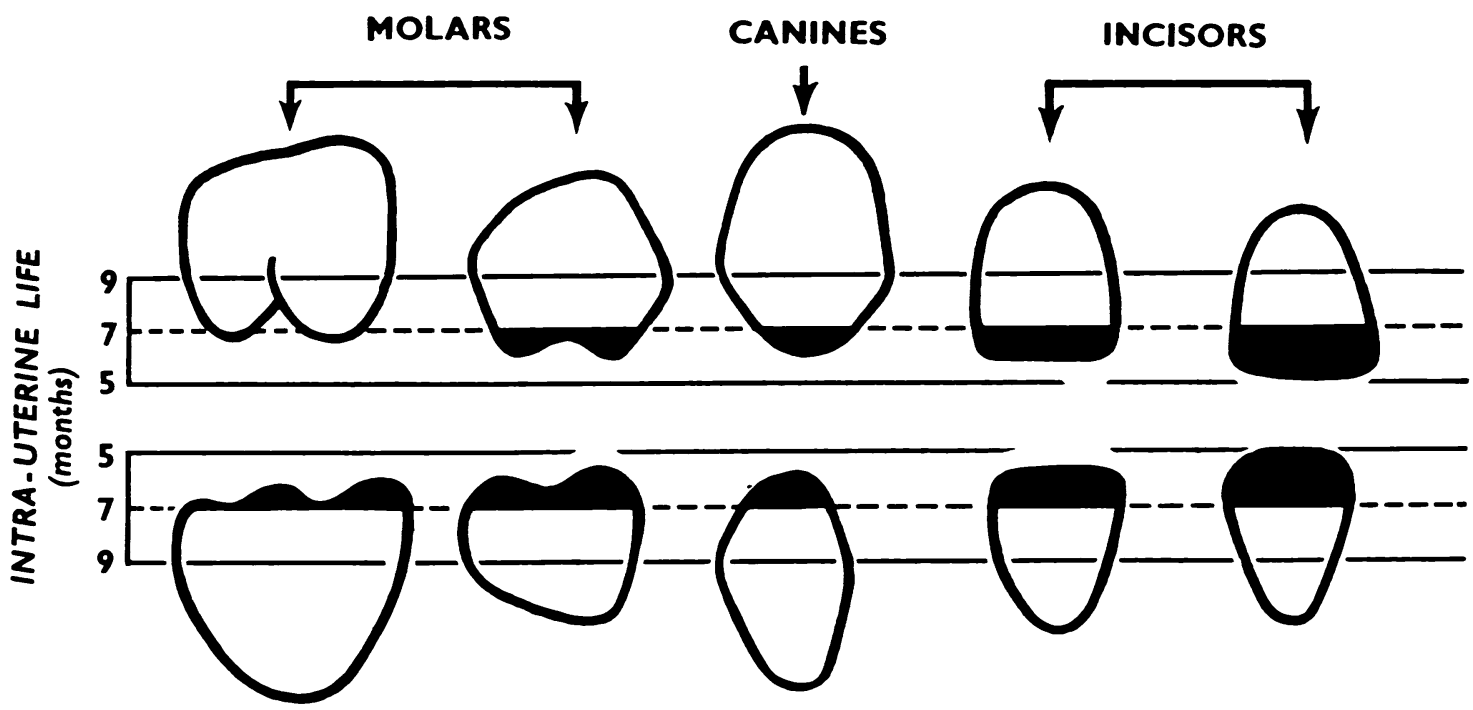

LOWER

FIG. 1.-The intra-uterine development of the crowns of the deciduous teeth. 
age of 6 months it was clear that P.H. had a severe cerebral palsy. Now, at the age of 3 years, he is unable to sit up. He has no speech and the lower limbs are spastic. He presents the clinical picture of severe kernikterus. The teeth show 'severe' enamel hypoplasia.

The other twin, also a boy, had a birth weight of $6 \mathrm{lb}$. $10 \mathrm{oz}$. and the Coombs test was positive. The haemoglobin of the peripheral blood shortly after birth was $96^{\circ}$; jaundice was apparent within the first 12 hours of life. The jaundice in this child was never as deep as in his twin, but he rapidly became anaemic. No exchange transfusion was done, but several simple transfusions were given. Apart from the anaemia this child's neonatal progress was satisfactory and there was never any clinical suggestion of kernikterus. He is now, at the age of 3 years, a normal healthy child. His teeth show neither pigmentation nor enamel hypoplasia.

Case 2 (T.L.). This child, a boy, was the sixth of normal parents. His mother was $\mathrm{Rh}$ negative with strong antibodies. His birth weight was $9 \mathrm{lb}$. and he developed severe and prolonged neonatal jaundice. He was born at home, and no treatment was given. His case in fact only came to light when his younger sister (D.L.) presented with retarded neuromuscular development. T.L. himself was also retarded in neuromuscular development, and now at the age of 7 years he is unsteady on his legs and has definite athetotic movements of his hands. He has a marked speech defect, associated with a severe high-tone deafness. (This aspect of his case has already been described in detail by Cavanagh (1954) who refers to him as 'Trevor L.')

His canine teeth show the 'ring' type of enamel lesion (Fig. 2). His sister D.L. is a typical, but more severe, case of kernikterus and has similar dental lesions.

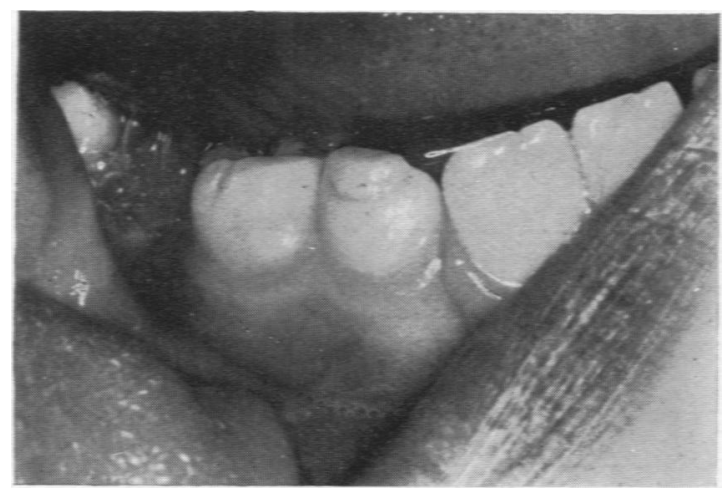

FiG. 2.-The right lower deciduous teeth of Case 2 (T.L.). The canine shows the typical 'ring' type of enamel hypoplasia.

Case 3 (P.S.). This infant, a boy, was the second child of healthy parents. The first child is alive and well. His mother was $R h$ negative with antibodies. His birth weight was $7 \mathrm{lb}$. The Coombs test was positive but the cord haemoglobin was $114^{\circ} \%$ and it was thought that he did not need exchange transfusion. He became deeply jaundiced, however, and on the third day of life he had marked neck retraction. He appeared to have recovered when he left hospital on the 21st day. At the age of $3 \frac{1}{2}$ months he presented with the first of a



Fig. 3. - The right half of the mandible of Case 3 (P.S.). The bone has been partly removed and the teeth left in situ. The groove of enamel hypoplasia is most marked on the canine.

series of hyperpyrexial attacks which recurred frequently until the time of his death at 8 months. The attacks followed the characteristic pattern described in severe forms of kernickterus (Patterson and Forrester, 1953). At the time of his death the lower central incisors had just erupted.

Post-mortem $x$-ray examination of the jaw showed a definite break in the continuity of the enamel outline of the canines. Dissection revealed a 'severe' enamel hypoplasia in the form of a deep groove across the lateral incisors, canines and first molars (Fig. 3).

Case 4 (B.B.). This boy was the sixth child of healthy parents. The previous children were normal. His mother was $\mathrm{Rh}$ positive. The child was born at home (birth weight $9 \mathrm{lb}$.) but as he developed severe jaundice he was admitted to hospital.

Apart from the jaundice no clinical evidence of haemolytic disease was discovered. There was no report of any neurological abnormality in the neonatal period. He presented at the age of 4 years with retarded neuromuscular development. He had not walked alone until well over the age of 2 years. When examined at the age of 5 years he was still ataxic and clumsy, and his hands showed athetotic movements. His speech was poorly developed and there was clinical evidence of deafness. (He was the only member of the family unable to hear the high-pitched bell of the ice-cream man.) Audiometry confirmed bilateral high-tone deafness.

The possibility of other blood group incompatibility was explored; specimens were taken from B.B. and from both parents. The report was as follows:

The mother was group $O R_{1} R_{1}(C C D e e)$, the father 
$A_{1} R_{2}(\propto D E)$ and the child, group $A_{1} R_{1} R_{2}(C c D E e)$. The anti-A in the mother's serum showed immune characteristics. No other abnormal antibodies were detected in the mother's serum.

Although ABO incompatibility may cause some difficulty in diagnosis it is now generally accepted as a cause of haemolytic disease and of kernikterus (Grumbach and Gasser, 1948; Boorman, Dodd and Trinick, 1949; Mitchell, Moss, Redner, Levy and Greenblatt, 1949; Reepmaker and van Loghem, 1953). This child (B.B.) appeared to satisfy both the clinical and serological criteria for the condition. His canine teeth showed the 'notch' form of enamel hypoplasia.

It is interesting to note that the next (seventh) infant in this family also developed severe and prolonged neonatal jaundice, but the teeth and the central nervous system are normal. The latest (eighth) infant was born in hospital and kept under close supervision. Jaundice appeared within the first 12 hours of life and at 48 hours the serum bilirubin was $19 \cdot 2 \mathrm{mg} .{ }^{\circ}$. Exchange transfusion was then undertaken and the subsequent progress has been satisfactory.

\section{Group II : Kernikterus in Premature Infants}

Under this heading nine children with cerebral palsy and enamel hypoplasia are described. All were premature infants and it seems probable that in each case the diagnosis was kernikterus of prematurity. As in the cases following haemolytic disease there was variation in the site and severity of the enamel lesion, and also modification by caries and attrition. The lesions were generally most severe on the incisors but the canines and the molars

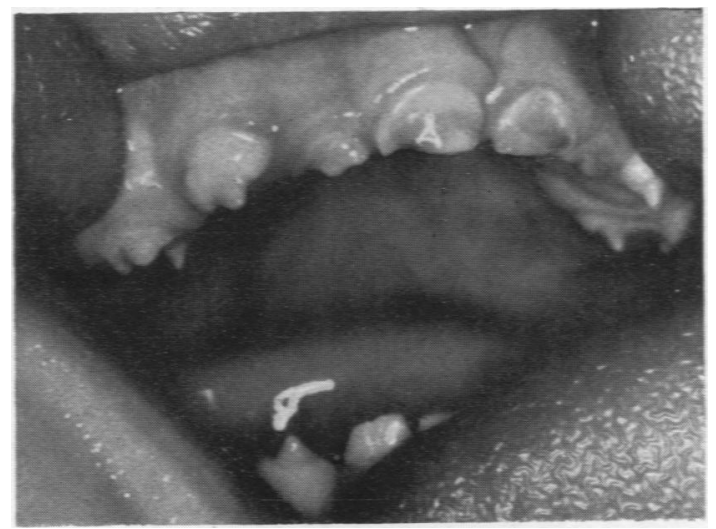

FiG. 4.-Widespread enamel hypoplasia in Case 19 (J.S.). The incisors are almost devoid of enamel; the canines and molars show spiky projections of the cusps. were often similarly affected. It was common for the incisal third of the incisor teeth to appear free of enamel; affected canines or molars, when seen soon after eruption, showed the tips of the cusps as small sharp spikes (Fig. 4). Attrition rapidly obscured this picture but there was always the story from the parents that the teeth "came through bad" or that they appeared "like little needles".

The details of these cases are set out in Table 1.

Amongst these cases there are two which merit further description.

Case 17 (B.M.). The patient was one of binovular twins. The other twin (birth weight $3 \mathrm{lb}$. $9 \mathrm{oz}$.) has developed normally, without evidence of cerebral palsy or of enamel hypoplasia.

Case 18 (L.S.). The cerebral palsy in this child, a girl, is in the form of a spastic diplegia and the clinical picture closely resembles that described by Ingram and Kerr (1954) as being frequently associated with retrolental fibroplasia. Her teeth (Fig. 5) are the only ones in the whole series which show a crescent-shaped erosion (Koupernik and Buhot, 1952).



Fig. 5.-The crescent-shaped erosion of the incisor teeth in Case 18 (L.S.).

In the present state of knowledge it seems necessary to exercise some caution in making the diagnosis of kernikterus of prematurity. It is clear, however, that this condition is being recognized with increasing frequency. From a pathological viewpoint accounts have been given by Aidin, Corner and Tovey (1950), Zuelzer and Mudgett (1950), Govan and Scott (1953), and Black-Schaffer, Kambe, Furuta and Moloney (1954). The later neurological sequelae have been accepted by Koupernik and Buhot (1952), Gerrard (1952) and Sacrez, Fruhling and Heumann (1952). These authors are agreed that the sequelae are indistinguishable whether they originate in prematurity or haemolytic disease.

The diagnosis in each individual case described must be the subject of opinion but there appears to be so much in common between our Group II cases that their description as a group is justified, and their very existence lends support to the concept 
TABLE 1

CLINICAL DETAILS OF GROUP II

\begin{tabular}{|c|c|c|c|c|}
\hline Case & $\begin{array}{l}\text { Birth } \\
\text { Weight } \\
\text { (lb. oz.) }\end{array}$ & $\begin{array}{l}\text { Exposure to } \\
\text { Raised Oxygen } \\
\text { Concentration } \\
\text { (Days) }\end{array}$ & Neonatal History & Present State \\
\hline (PD) & $3-5$ & 16 & $\begin{array}{l}\text { No unusual incidents recorded; no record of } \\
\text { jaundice. Early changes of retrolental fibro- } \\
\text { plasia, but eyes now normal. }\end{array}$ & $\begin{array}{l}\text { Cerebral palsy with spastic legs and bilateral } \\
\text { internal strabismus. She cannot sit unaided } \\
\text { at the age of } 2 \text { years. }\end{array}$ \\
\hline $\begin{array}{l}15 \\
(V G)\end{array}$ & $2-8$ & 44 & $\begin{array}{l}\text { Frequent cyanotic attacks between } 15 \text { th and } 21 \text { st } \\
\text { day of life. No record of jaundice. Early } \\
\text { changes of retrolental fibroplasia, but eyes now } \\
\text { normal. }\end{array}$ & $\begin{array}{l}\text { Cerebral palsy of hypotonic type. She is } \\
\text { beginning to walk alone at the age of } 3 \text { years. }\end{array}$ \\
\hline$\stackrel{16}{16}$ & 4-0 & 12 & $\begin{array}{l}\text { General condition and progress normal apart } \\
\text { from marked jaundice which lasted from the } \\
\text { 3rd to the } 13 \text { th day of life. Early changes of } \\
\text { retrolental fibroplasia were noted on the } \\
\text { 22nd day. }\end{array}$ & $\begin{array}{l}\text { Cerebral palsy with mildly spastic legs and } \\
\text { hypotonic trunk muscles. Left eye normal; } \\
\text { right eye incomplete retrolental membrane. }\end{array}$ \\
\hline (B.M.) & $2-5$ & 14 & $\begin{array}{l}\text { Normal development. The eyes were examined } \\
\text { regularly. No evidence of retrolental fibro- } \\
\text { plasia. }\end{array}$ & $\begin{array}{l}\text { Mild cerebral palsy with delayed walking. } \\
\text { She did not sit alone until the age of } 1 \text { year } \\
\text { and at } 2 \frac{1}{2} \text { years she has a wide-based, } \\
\text { unsteady gait, and bilateral internal strabis- } \\
\text { mus. }\end{array}$ \\
\hline (L.S.) & $2-15$ & 54 & $\begin{array}{l}\text { Uneventful except for severe jaundice which had } \\
\text { cleared by the } 16 \text { th day. Fundi not examined } \\
\text { in the neonatal period. }\end{array}$ & $\begin{array}{l}\text { Blind; complete bilateral retrolental mem- } \\
\text { branes. Cerebral diplegia; she is beginning } \\
\text { to stand with both hands held at the age } \\
\text { of } 3 \text { years. }\end{array}$ \\
\hline $\begin{array}{l}19 \\
\text { (J.S.) }\end{array}$ & $3-3$ & 36 & $\begin{array}{l}\text { Cyanotic attacks on the } 6 \text { th day only; no record } \\
\text { of jaundice. Mild early changes of retro- } \\
\text { lental fibroplasia, but now normal. }\end{array}$ & $\begin{array}{l}\text { Athetoid type of cerebral palsy. Clinical } \\
\text { evidence of deafness. He is beginning to } \\
\text { stand with hands held at age of } 2 \text { years. }\end{array}$ \\
\hline (B.W.) & $4-0$ & ? & $\begin{array}{l}\text { Intermittent cyanotic attacks up to age of } 21 \\
\text { days; jaundice of unspecified duration; fundi } \\
\text { not examined; no record of oxygen adminis- } \\
\text { tration. }\end{array}$ & $\begin{array}{l}\text { Cerebral palsy with delayed walking and } \\
\text { speech. He first sat alone at the age of } \\
15 \text { months; now at the age of } 6 \text { years he } \\
\text { walks almost normally, but shows con- } \\
\text { siderable incoordination when attempting to } \\
\text { run. There is clinical evidence of high tone } \\
\text { deafness. His eyes are normal. }\end{array}$ \\
\hline $\begin{array}{l}21 \\
\text { (S.K.) }\end{array}$ & $2-9$ & 41 & $\begin{array}{l}\text { Jaundice recorded as slight from the } 2 \text { nd to the } \\
\text { 8th day; nothing otherwise abnormal. The } \\
\text { eyes were not examined in the neonatal period. }\end{array}$ & $\begin{array}{l}\text { Blind; complete bilateral retrolental mem- } \\
\text { branes. Cerebral palsy of hypotonic type } \\
\text { with delayed sitting and walking. He is } \\
\text { just walking with hands held at the age of } 3 \frac{1}{2}\end{array}$ \\
\hline (S.R.) & $4-6$ & (1 hour) & $\begin{array}{l}\text { Mild jaundice noted on the 4th day, otherwise } \\
\text { nothing abnormal. Eyes examined regularty; } \\
\text { no evidence of retrolental fibroplasia. }\end{array}$ & $\begin{array}{l}\text { Mild cerebral paky. He did not sit alone } \\
\text { until the age of } 15 \text { months. At } 20 \text { months } \\
\text { he is beginning to pull himself to standing } \\
\text { and to use his hands to feed himself. }\end{array}$ \\
\hline
\end{tabular}

of a common basic pathological process in all forms of kernikterus.

A history of neonatal jaundice has sometimes been lacking in the Group II cases. This is not unexpected, for they were observed by many different individuals and under different conditions of lighting. There will be marked differences between observers in describing the depth of jaundice observed in any one case, and the colour of the skin is a very inaccurate measure of the serum bilirubin (Davidson, Merritt and Weech, 1941). Often jaundice, although observed, goes unrecorded in the premature infant as it is so common and so widely regarded as physiological.

The relationship between $\mathrm{ABO}$ incompatibility and kernikterus of prematurity has been much discussed. Gerrard (1950) found no such relationship, but Levine, Vogel and Rosenfield (1953) suggest that such incompatibility may play at least a part in this condition. All the cases in Group I were subjected to a full serological examination. The results are set out in Table 2. It will be noted that there are only five cases in which incompatibility can be excluded as a contributory factor (Nos. 14, $17,20,21,22)$; in no case, however, had there been obvious evidence of haemolytic disease in the neonatal period.*

\section{The Incidence of Enamel Hypoptasia in Other Conditions}

There are few studies on enamel hypoplasia in deciduous teeth. Mellanby and Mellanby (1950) report the incidence of 'gross hypoplasia' in normal children as $0.7^{\circ} \%$ and those cases appear to have shown changes which would generally correspond to the lesions described in this paper as 'mild'. No lesions comparable to a 'severe' type were described. Amongst 136 rachitic children, Shelling and Anderson (1936) reported an $18 \%$ incidence of enamel hypoplasia, but did not describe the nature of the lesions.

Hess and Abramson (1931), although unable to

* The serology in these cases was carried out at the National Blood Transfusion Laboratories, Manchester, by Dr. P. H. Renton and Dr. F. Stratton and may be the subject of a more detailed report at a later date. 
TABLE 2

SEROLOGICAL INVESTIGATION OF GROUP II CASES

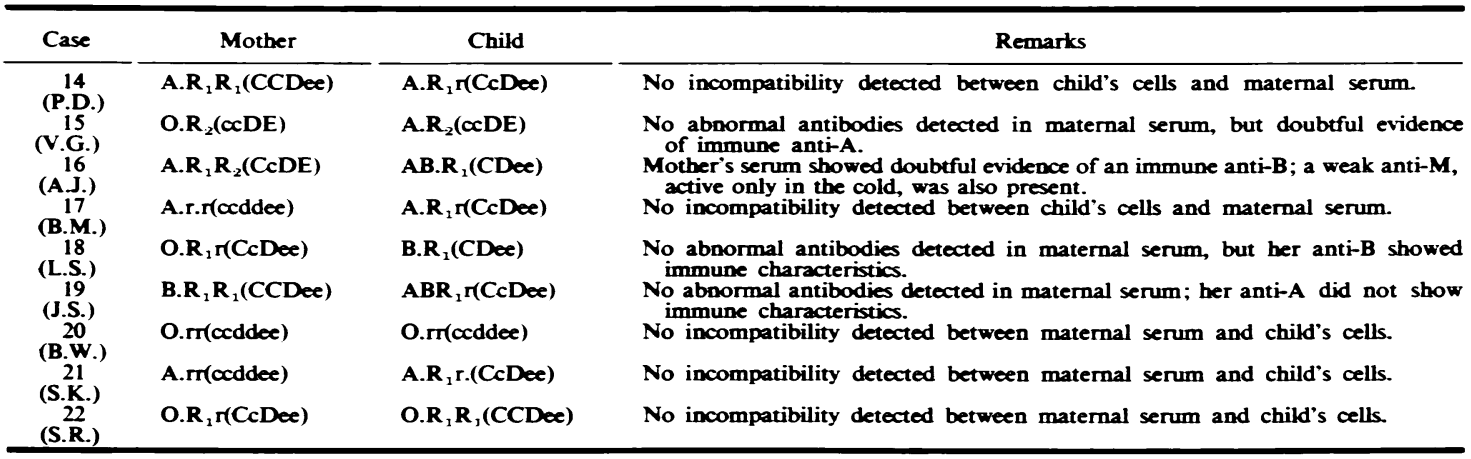

associate enamel hypoplasia with any one disease, noted that amongst their cases 'the number of premature children was inordinately high.' Stein (1947) observed severe enamel hypoplasia involving the incisal third of the incisors in eight out of 16 premature infants.

Schour and Kronfeld (1938) record one further example of enamel hypoplasia which was as severe as that reported in this paper. Their patient appears to have suffered from cerebral palsy, and it is interesting to note in retrospect that the history and post-mortem findings are entirely consistent with a diagnosis of kernikterus.

The existence of enamel hypoplasia in a sporadic form made it necessary to examine our own cases critically and to make sure that the dental lesions were not associated with some underlying pathological cause other than kernikterus. It was obvious that in Group I, haemolytic disease itself, rather than kernikterus, was a selecting factor. In Group II retrolental fibroplasia and prematurity were selecting factors. In both groups cerebral palsy of varying degree was present and could have exercised a similar selecting influence. It was necessary, therefore, to study the incidence of enamel hypoplasia in these and other conditions, when not associated with kernikterus.

Normal Children. One hundred and nine toddlers were examined. All these children were making routine attendances at an infant welfare clinic; all were reported to be well. 'Mild' hypoplasia was found in four cases, but on looking into their histories it was noted that three had been premature infants with birth weights close to $5 \mathrm{lb}$. The fourth was the child of a mother who had syphilis; this condition was discovered and treated during the pregnancy and the child was otherwise normal. No other examples of hypoplasia were found in this group of children.

Haemolytic Disease. Forty-five children were examined. Each satisfied the criteria of $\mathrm{Rh}$ incompatibility: a positive Coombs test and clinical evidence of haemolytic disease. All except one were full-term infants. Thirteen had had exchange transfusions. 'Mild' enamel hypoplasia was discovered in nine cases and green teeth in seven. No examples of 'severe' hypoplasia were found. None of these children showed any neurological disturbance.

TABLE 3

INCIDENCE OF SEVERE ENAMEL HYPOPLASIA IN CONTROL GROUPS

\begin{tabular}{|c|c|c|c|c|c|}
\hline \multirow{2}{*}{\multicolumn{3}{|c|}{ Group }} & \multirow[t]{2}{*}{ Total Cases Examined } & \multicolumn{2}{|c|}{ Severe Enamel Hypoplasia } \\
\hline & & & & Total & $\%$ Incidence \\
\hline Normal children & . & . & $\begin{array}{l}109 \text { less } 4 \text { cases ( } 3 \text { premature and one } \\
\text { maternal syphilis) }=105\end{array}$ & $\mathbf{0}$ & 0 \\
\hline Haemolytic disease without kernikterus & . & . & 45 & $\mathbf{0}$ & $\mathbf{0}$ \\
\hline $\begin{array}{l}\text { Premature infants with retrolental fibr } \\
\text { birth weight } 3 \text { lb.) }\end{array}$ & roplasia & (average & 65 less 3 with kernikterus $=62$ & 9 & $9,62=16 \%$ \\
\hline Unselected premature infants & . & . & 34 & 7 & $7 / 34=20 \%$ \\
\hline Cerebral palsy (other than kernikterus) & . & . & 11 & $\mathbf{0}$ & $\mathbf{0}$ \\
\hline
\end{tabular}


Enamel hypoplasia and pigmentation were found together in only one case.

Premature Infants. Ninety-nine infants were examined. They were drawn from two separate sources.

A first group of 65 were examined in the Sunshine Homes of the Royal National Institute for the Blind; all had been blinded by retrolental fibroplasia; their birth weights ranged from $2 \frac{1}{2}$ to $4 \frac{1}{2} \mathrm{lb}$. (average $3 \mathrm{lb}$.). 'Severe' enamel hypoplasia was found in 12 cases, being most marked in three children who also showed definite evidence of retarded neuromuscular development. Both dentally and neurologically these three were indistinguishable from the children described in Group II as examples of kernikterus. The enamel lesions in the other nine cases were similar to those described below as occurring in normal premature infants.

Thirty-four premature infants were seen in a routine follow-up clinic. Their birth weights ranged from $2 \mathrm{lb}$. $5 \mathrm{oz}$. to $4 \mathrm{lb}$. $10 \mathrm{oz}$. (average $3 \mathrm{lb} .10 \mathrm{oz}$.). 'Severe' enamel hypoplasia was found in seven cases. In all seven, however, it was limited to the upper central incisors, and affected only one or two millimetres of the incisal edge of the tooth. In none of these cases was there any evidence of cerebral palsy.

Cerebral Palsy. Twelve children with cerebral palsy were examined. All were between the ages of 3 and 5 years and were making routine attendances at out-patient clinics. Eleven had normal teeth; the twelfth had 'severe' enamel hypoplasia; on going into her history it was found that she had been a premature infant with a birth weight of $3 \mathrm{lb} .13 \mathrm{oz}$. and that she had had severe neonatal jaundice. She had an ataxic form of cerebral palsy and was known to have partial bilateral nerve deafness. She was regarded, on clinical grounds, as a further case of kernikterus of prematurity.

It is now possible to compare the incidence of 'severe' enamel hypoplasia in these control groups (Table 3). In each group the cases regarded as further examples of kernikterus have been excluded from the calculation of incidence. The low incidence of hypoplasia in normal children is in accordance with Mellanby's findings. The comparatively high incidence in premature infants agrees with the findings of Stein and of Hess and Abramson.

It is emphasized, however, that although 'severe' hypoplasia was otserved in normal premature infants it was almost entirely confined to the upper central incisors, whereas when associated with cerebral palsy the lesion was widespread throughout the deciduous dentition.

\section{Discussion}

It has already been noted that the site of hypoplasia on a tooth is related to the age at which metabolism was disturbed. This concept fits closely with our own findings. Thus in the premature infants (Group II) the incisors have always been severely involved; the canines and molars have usually been affected at the cusp tip. In the cases of full-term infants (Group I) the incisors have often been normal, and the lesions on the canines and molars have been nearer the gum margin.

It has been interesting to note the absence of green pigmentation in the cases with 'severe' hypoplasia. Pigmentation, when it does occur, is most evident in the dentine (Miller, 1951; Marsland and Gerrard, 1953). The absence of the pigment in the cases now reported suggests that the disturbance responsible for the enamel lesion may also have been severe enough to arrest development of the dentine. Preliminary investigation of material from these cases supports this hypothesis, and also suggests that the neonatal lines' which can be seen in 'normal' enamel may be associated with 'physiological' neonatal jaundice.

The relationship between enamel hypoplasia and bilirubin itself requires further study; work on this and on related matters is in progress and will be reported in detail at a later date. It seems certain from the occurrence of these enamel lesions that severe metabolic disturbance is associated with both severe haemolytic disease and premature birth. It seems that in both types the disturbance occurs in the first few days of extrauterine life.

Microscopically the enamel which is formed pre-natally can be distinguished from that which is formed post-natally by the neonatal line of Rushton (1933). It was observed in the 'severe' hypoplastic areas that there was prenatal enamel but no postnatal enamel. This indicates that the lesions resulted from a metabolic disturbance shortly after birth and offers further evidence in support of the view that kernikterus is a post-natal phenomenon.

The similarity between the pathological and the neurological changes recognized in all forms of kernikterus has suggested a common underlying factor, which Govan and Scott (1953) thought might be anoxia. Other writers have tended to incriminate bilirubin. Black-Schaffer et al. (1954) have recently summarized these views. Which, if either, of these two possible causes is related to the enamel lesion is a matter for conjecture and experiment. It seems probable, however, that the elucidation of the dental problem may throw some light on the aetiology of kernikterus itself.

Apart from the significance of these changes from 
the dental and pathological viewpoint, their presence in any individual can be of direct help in clinical practice. The discovery of typical changes in any case of cerebral palsy will suggest a diagnosis of kernikterus, and this in turn will lead to the suspicion that partial deafness may complicate the child's disability. The presence of kernikterus may be anticipated by the discovery of typical $x$-ray changes before any teeth have erupted and before retarded neuromuscular development has become apparent.

From an otologist's viewpoint the presence of these lesions in any case of congenital deafness should lead at once to enquiry into the possibility of kernikterus.

\section{Summary}

In 13 cases of kernikterus following haemolytic disease an acute enamel hypoplasia of the deciduous teeth was observed. Similar lesions were found in nine premature infants who had developed cerebral palsy; these cases are tentatively cited as examples of 'kernikterus of prematurity'.

Similar but milder enamel lesions have been found in normal premature infants but not in fullterm children in the absence of kernikterus.

The cause of the enamel lesion is not established but it is suggested that the elucidation of this problem may throw some light on the cause of the damage to the central nervous system. Attention is drawn to the diagnostic value of these changes in cases of cerebral palsy or congenital deafness.

We wish to thank Mrs. F. Cavanagh, Dr. T. N. Fisher, Professor W. F. Gaisford, Dr. S. K. Guthrie, Dr. A. Holzel, Dr. G. M. Komrower, Dr. R. I. Mackay, Dr. N. Wells and Dr. B. Wolman, for permission to examine their cases.

Dr. C. E. Potter and Mr. M. Colborne Brown kindly permitted us to examine the children in the Sunshine Homes; we are indebted to the headmistresses and staff of the Sunshine Homes at Southport, Kingswinsford, Leamington and Northwood for their help.
The Department of Medical Illustration, Manchester Royal Infirmary, have provided all the illustrations.

Our thanks are due to Professor W. F. Gaisford and Professor H. G. Radden for their help and advice in preparing this paper.

\section{REFERENCES}

Aidin, R., Corner, B. and Tovey, G. (1950). Lancet, 1. 1153.

Bevis, D. C. A. (1955). J. Obstet. Gynaec. Brit. Emp. (In the press.) Black-Schaffer, B., Kambe, S.,Furuta, M. and Moloney, W. C. (1954). Amer. J. Dis. Child., 87, 737.

Boorman, K. E., Dodd, B. E. and Teinick, R. H. (1949). Lancet, 1, 1088.

Boyle, P. E. and Dinnerman. M. (1941). Amer. J. Orthodont. (Oral Surg.), 27, 377.

Cavanagh, F. (1954). J. Laryng., 68, 444.

Cavanagh, F. (1954). J. Laryng., 68, 44

Davidson, L. T., Merritt, K. K. and Weech, A. A. (1941). Amer. J. Dis. Child., 61. 958.

Ellis, R. W. B. (1938). Proc. roy. Soc. Med., 31, 767.

Farquhar, D. A. B. (1951). Aust. J. Dent., 55, 207.

Forrester, R. M., Jefferson, E. and Naunton, W. J. (1954). Lancet, $2,258$.

Gerrard J W. (1950) Ibid. 235.

(1952). Brain, 74, 526.

(1954). Personal communication.

Govan, A. D. T. and Scott, J. M. (1953).

Hess A. F, A. and Gasser, C. (1948). Helv. paediat. Acta, 3, 447.

(1931). Dent. Cos., 73, 849 .

Ingram, T. T. S. and Kerr, J. D. (1954). Archives of Disease in Childhood, 29, 282.

Kölb, H and Rosenkranz A. (1952). Öst. Z Kinderheilk 7, 216

Koupernik, C. and Buhot, S. (1952). Ost. Z. Kinderheilk., 7, 216.

Levine, P., Vogel, P. and Rosenfield, R. E. (1953). Advanc. Pediat. 6. 97. Losch, P. K., Brown, J. C. and Boyle, P. E. (1940). J. dent. Res.,

MacRae, D. J. (1952). Proc. roy. Soc. Med., 45, 439.

Marsland, E. A. and Gerrard. J. W. (1953). Brit. dent. J., 94, 305.

Mellanby, H. and Mellanby, M. (1950). Brit. med. J. i, 1341.

Mellanby, H. and Mellanby, M. (1950).

Miller, J. (1951). Brit. dent. J., 91, 121 .
Mitchell, N., Moss, A. H., Redner, B., Levy, H. and Greenblatt, I. J. (1949). Pediatrics, 3, 813.

Nickerson, D. A. and Moulton. R. T. (1943). New. Engl. J. Med., 229. 863 .

Patterson, W. H. and Forrester, R. M. (1953). Archives of Disease in Childhood, 28, 217.

Parsons, L. (1947). Lancet, 1, 815.

Pickles, M. M. (1949). Haemolytic Disease of the Newborn, p. 146. Oxford.

Potter, E. L. (1947). Rh., p. 198. Chicago.

Reepmaker, J. and van Loghem. J. J. (1953). Vox Sanguinis, Amat., $3,143$.

Rushton, M. A. (1933). Dent. Rec., 53, 170

Sacrez, R., Fruhling, L. and Heumann, G. (1952). Pediatrie, 7. 731.

Schour, I. and Kronfeld, R. (1938). Arch. Path., Chicago, 26, 471.

Shelling. D. H. and Anderson, G. M. (1936). J. Amer. dent. Ass. 23. 840 .

Stein, G. (1947). Amer. J. Orthodont. (Oral Surg.), 33, 831.

Stones, H. H. (1951). Oral and Dental Diseases, 2 nd ed., p. 518 Edinburgh.

Tank, G. (1951). J. Amer. dent. Ass., 42.302.

Thursfield, H. (1912). Proc. roy. Soc. Med., Vol. 5. (Section for the study of disease in children), p. 147

Zuelzer, W. W. and Mudgett. R. T. (1950). Pediatrics, 6, 452. 